Jurnal At-Tibyan: Jurnal Ilmu Alqur'an dan Tafsir Volume 5 No. 1, Juni 2020 (h.74-89)

P ISSN 2442-594X | E ISSN 2579-5708

http://journal.iainlangsa.ac.id/index.php/tibyan

\title{
ARAH BARU PENGEMBANGAN ULUMUL QUR'AN: TELAAH METODOLOGIS ILMU ASBABUN NUZUL
}

The New Development Of Ulumul Qur'an (The Methodological Studies of Asbab AlNuzul)

\section{Munawir}

Institut Agama Islam Negeri Purwokerto

munawir.0510@gmail.com

\section{Musta'in}

Institut Agama Islam Negeri Purwokerto

mustaindakwah@gmail.com

DOI: $10.32505 /$ tibyan. v5i1.1221

\begin{tabular}{|c|c|c|}
\hline Submitted: 04-11-2019 & Revised: 18-06-2020 & Accepted: 26-06-2020 \\
\hline
\end{tabular}

\begin{abstract}
Abstrsct
In its corridor as a science, the science of asbabun nuzul is on a par with other scholars. Even though it was constructed by scholars, it did not necessarily make it immune to criticism and immune to development; there are always areas that are unthinkable and not even thought of. This is the focus of this article's discussion. Through qualitative-interpretative methods and philosophical approaches (philosophical approaches), critical approaches (critical approaches), and constructivist approaches, the results are obtained that the areas that have not been and are not even thought of at the same time as the development of contemporary asbabun nuzul science is the formulation of macro asbabun nuzul theory, and the formulation the rules of al-ibratu bil maqashidi.
\end{abstract}

Keywords: Asbabun Nuzul, Construction, Deconstruction, Reconstruction

\begin{abstract}
Abstrak
Dalam koridornya sebagai ilmu, ilmu asbabun nuzul adalah sejajar dengan keilmuan-keilmuan lainnya. Sekalipun ia dikonstruksi oleh para ulama, tidak lantas menjadikannya kebal kritik dan imun terhadap pengembangan; selalu ada wilayah yang belum dipikirkan dan bahkan tidak terpikirkan. Inilah yang menjadi focus pembahasan artikel ini. Melalui metode kualitatif-interpretative dan pendekatan filosofis (philosophical approach), pendekatan kritis (critical approach), dan pendekatan konstruktivis, diperoleh hasil bahwa wilayah yang
\end{abstract}


belum dan bahkan tidak terpikirkan sekaligus sebagai pengembangan ilmu asbabun nuzul kekinian adalah dirumuskannya teori asbabun nuzul makro, dan dirumuskannya kaidah al-ibratu bil maqashidi.

Kata Kunci: Asbabun Nuzul, Konstruksi, Dekonstruksi, Rekonstruksi

\section{Pendahuluan}

Ilmu asbabun nuzul, sekalipun ia berhubungan dengan Kitab Suci dan karenanya memiliki kedudukan tinggi dalam ulumul Qur'an, namun dalam konteks sebagai bangunan ilmu, ia tetap dilekati hukum-hukum dan prosedur-prosedur sebagaimana ilmu-ilmu pada umumnya.

Ilmu asbabun nuzul yang notabene-nya sebuah bangunan keilmuan hasil rumusan para ulama abad kedua Hijriyyah, dalam koridornya sebagai ilmu, tentu seiring dengan perjalanan sejarah kehidupan manusia dengan segala kompleksitas problematika yang ada di dalamnya menjadikan bangunan ilmu asbabun nuzul rumusan ulama abad kedua Hijriyah tersebut banyak mengalami anomali atau bahkan krisis sehingga meniscayakan adanya pengembangan keilmuan sesuai dengan tuntutan dan kebutuhan zaman. Point inilah yang menjadi titik kemenarikan penulis untuk mengkaji dan meneliti secara lebih lanjut, yaitu mengkaji dan meneliti tentang konstruksi, dekonstruksi, dan rekonstruksi ilmu asbabun nuzul.

\section{Prior Research Kajian Asbabun Nuzul}

Kajian asbabun nuzul, memang sudah banyak dikaji oleh para peneliti yang memiliki concern terhadap studi ilmu Al-Qur'an. Penulis menemukan ada beberapa artikel tentang asbabun nuzul yang sudah di-publish di jurnal-jurnal terakreditasi nasional. Namun, dari beberapa artikel yang penulis telaah tersebut, secara umum hanya berisi deskripsi normatif tentang ilmu asbabun uzul sebagaimana yang dirumuskan oleh para ulama terdahulu (baca: klasik). Di antara artikel-artikel tersebut adalah arikel berjudul Asbabun Nuzul sebagai Cabang Ulumul Qur'an tulisan Ridhaul Wahidi tahun 2016.1 Senada dengan ini adalah artikel berjudul Asbabun Nuzul Pengertian, Macam-macam, Redaksi, dan Urgensi karya Pan Suaedi tahun 2018.2 Dua artikel ini membahas secara normatif dan informatif mengenai hal ihwal seputar cakupan kajian asbabun nuzul. Dua artikel ini penting untuk mengantarkan pembaca pada gambaran umum ilmu asbabun nuzul.

Berikutnya, artikel yang mengkaji asbabun nuzul lebih dalam lagi, yaitu artikel Asbabun Nuzul sebagai Langkah Awal Menafsirkan Al-Qur'an tulisan Wahyudin pada

\footnotetext{
${ }^{1}$ Ridhaul Wahidi, “Asbabun Nuzul sebagai Cabang Ulumul Qur'an”, dalam Jurnal Syahadah, 3, no. 1 (2016): 53-66.

${ }^{2}$ Pan Suaedi, “Asbabun Nuzul Pengertian, Macam-macam, Redaksi, dan Urgensi”, dalam Almufida 1, no. 1 (2018): 110-122.
} 
tahun 2010,3 dan artikel berjudul Asbabun Nuzul dan Urgensinya dalam Memahami Al-Qur'an karya Muhammad Alifudin tahun 2012.4 Kedua artikel ini satu langkah lebih maju dari dua artikel sebelumnya, karena di samping menyajikan teori juga aplikasinya dalam menafsiri Al-Qur'an.

Terakhir artikel berjudul Asbabun Nuzul Perspektif Mikro dan Makro tulisan Nunung Sisfita tahun 2015.5 Sekalipun terbit labih lama, akan tetapi dari segi kajian, artikel ini lebih maju lagi dibanding artikel-artikel sebelumnya. Artikel ini menyajikan pembahasan asbabun nuzul kontemporer yang digagas oleh Fazlur Rahman, khususnya asbabun nuzul makro.

Mengacu prior research terhadap kajian-kajian di atas, artikel yang penulis tulis ini, memiliki nilai beda. Nilai beda tersebut adalah pada aspek alur pikir kontinuitas kajian ilmu asbabun nuzul yang dipaparkan di dalamnya. Kontinuitas yang dimaksud adalah dialektika antara konstruksi ilmu asbabun nuzul, dekonstruksi ilmu asbabun nuzul, dan rekonstruksi ilmu asbabun nuzul. Dengan ini, artikel penulis ini bisa menjadi kajian komprehensif (menampung dan menyempurnakan) kajian-kajian sebelumnya. Di samping itu, dengan dialektika kritis, artikel ini juga menyajikan pembahasan sehingga arah baru pengembangan ilmu asbabun nuzul menjadi lebih kentara.

\section{Gambaran Umum Ilmu Asbabun Nuzul Pengertian Asbabun Nuzul}

Asbabun Nuzul, ditinjau dari aspek etimologi, merupakan satu istilah yang terdiri dari dua kata tetapi membentuk satu makna, istilah seperti ini dalam bahasa Arab disebut dengan tarkib idhafi. Dua kata tersebut adalah kata asbab dan kata al-nuzul. Kata asbab adalah bentuk plural (jama') dari kata tunggal (mufrad) sabab yang artinya 'sebab' atau 'latar belakang', sedang kata al-nuzul adalah bentuk masdar dari kata nazala yang artinya 'turun'.6 Dengan ini, asbabun nuzul diartikan dengan sebab-sebab (latar belakang) turunnya Al-Qur'an. Digunakannya kata 'nuzul' (yang artinya turun) untuk konteks Al-Qur'an, hal ini karena didasarkan pada fenomena Al-Qur'an yang keberadaannya bersumber dari Tuhan Yang Maha Tinggi yang diturunkan kepada Nabi-Nya (yang hakikatnya adalah makhluk), sehingga pewahyuan Al-Qur'an dibahasakan dengan diturunkan dari pihak atas ke pihak bawah. Berbeda untuk konteks

\footnotetext{
${ }^{3}$ Wahyudin, “Asbabun Nuzul sebagai Langkah Awal Menafsirkan Al-Qur'an”, dalam JSH Jurnal Sosial Humaniora 3, no. 1 (2010): 192-203.

${ }^{4}$ Muhammad Alifudin, “Asbabun Nuzul dan Urgensinya dalam Memahami Al-Qur'an”, dalam Shautut Tarbiyah, Ed. 26,Th. XVIII, Mei 2012.

${ }^{5}$ Nunung Sisfita, “Asbabun Nuzul Perspektif Mikro dan Makro’, dalam Tasamuh 13, no. 1 (2015): 69-80.

${ }^{6}$ Sebagai catatan, kata turun di atas maksudnya adalah turunnya Al-Qur'an, sebab ilmu asbabun nuzul adalah cabang ilmu dari ulumul Qur'an, sehingga sebagian ulama tidak menyebutkan Al-Qur'an di belakang kata nuzul karena sudah maklum adanya. Muhammad Amin Suma, Ulumul Qur"an, Cet. I (Jakarta: PT Raja Grafindo, 2013), 205.
} 
hadis yang menggunakan istilah al-wurud (yang artinya kedatangan), karena keberadaan hadis bersumber dari Nabi sendiri.

Selanjutnya, asbabun nuzul ditinjau dari aspek epistimologinya para ulama memiliki keragaman pendapat, di antaranya:

M. Hasbi Ash Shiddieqy, ia mendefinisikan asbabun nuzul dengan satu pengertian:

Kejadian yang karenanya diturunkan Al-Qur'an untuk menerangkan hukumnya di hari timbul kejadian-kejadian itu dan suasana yang di dalamnya Al-Qur'an diturunkan serta mebicarakan sebab yang tersebut itu, baik diturunkan langsung sesudah terjadi sebab itu ataupun kemudian lantaran suatu hikmah. ${ }^{7}$

Nurcholis Madjid (seorang cendikiawan muslim Indonesia), ia mengartikan asbabun nuzul dengan sebuah definisi:

Konsep, teori, atau berita tentang adanya sebab-sebab turunnya wahyu tertentu dari Al-Qur'an kepada Nabi SAW, baik berupa satu ayat, satu rangkaian ayat maupun satu surat. ${ }^{8}$

Selanjutnya Subhi Shalih, ia menyatakan bahwa asbabun nuzul itu sangat berkenaan dengan:

Sesuatu yang menjadi sebab turunnya sebuah ayat atau beberapa ayat, atau suatu pertanyaan yang menjadi sebab turunnya ayat sebagai jawaban, atau sebagai penjelasan yang diturunkan pada waktu terjadinya suatu peristiwa. ${ }^{9}$

Al-Zarqani, dalam kitab Manahilul Irfan fi Ulumil Qur'an ia berpendapat bahwa asbabun nuzul adalah:

Keterangan mengenai suatu ayat atau rangkaian ayat yang berisi tentang sebabsebab turunnya atau menjelaskan hukum suatu kasus pada waktu kejadiannya. ${ }^{10}$

Dari beberapa pengertian sebagaimana yang dikemukakan oleh para pakar di atas, maka diambil simpulan bahwa asbabun nuzul sangat berkaitan dengan dua hal; pertama, berkaitan dengan adanya sebuah peristiwa yang melatari diturunkannya alQur'an, ${ }^{11}$ dan kedua, berkaitan dengan adanya sebuah pertanyaan yang diajukan kepada Rasulullah kemudian al-Qur'an turun sebagai jawaban dari pertanyaan tersebut. ${ }^{12}$

${ }^{7}$ M. Hasbi Ash Shiddieqy, Sejarah dan Pengantar Ilmu Al-Qur'an/Tafsir (Jakarta: Bulan Bintang, 1990), 69. Dikutip dari Muhammad Chirzin, Al-Qur'an dan Ulumul Qur'an (Yogyakarta: Dana Bhakti Prima Yasa, 1998), 30.

${ }^{8}$ Nurcholis Madjid, "Konsep Asbabun Nuzul: Relevansinya Bagi Pandangan Historis Segi-segi Tertentu Pandangan Keagamaan”, dalam Budhy Munawar Rahman (ed.), Kontekstualisasi Doktrin Islam dalam Sejarah (Jakarta: yayasan Paramadina, 1994), 24. Dikutip dari Muhammad Chirzin, Al-Qur'an, 30 .

${ }^{9}$ Shubhi Shalih, Membahas Ilmu-ilmu Al-Qur'an, Terjemah Nur Rakhim dkk (Jakarta: Pustaka Firdaus, 1993), 160. Dikutip dari Muhammad Chirzin, Al-Qur'an, 30.

${ }^{10}$ Al-Zarqani, Manahil 'Irfan Fi Ulum al-Qur'an, Jilid I (Beirut: Dar al-Fikr, 1988), 106. Dikutip dari Muhammad Chirzin, Al-Qur'an, 30.

${ }^{11}$ Contoh riwayat dari Ibnu Abbas tentang perintah Allah kepada Rasulullah untuk memberi peringatan kepada kerabatnya. Dalam rangka itu, Rasulullah naik ke bukit Shafa lalu menyampaikan peringatan kepada kaum kerabatnya perihal adanya siksa yang pedih. Mendengar peringatan Rasulullah tersebut, Abu Lahab mencaci Rasulullah seraya mengatakan: 'Celakalah Engkau wahai Muhammad! 
Selanjutnya, terlepas dari definisi di atas, sebenarnya ada satu problem teologis yang harus dijelaskan kaitannya dengan penggunaan istilah asbab al-nuzul. Sebagaimana paparan di atas, kata $a s b a b$ adalah bentuk jamak dari kata $s a b a b$ yang dalam bahasa Indonesia diterjemahkan dengan sebab-sebab, sehingga di sinilah problem teologis itu muncul. Oleh karena asbab al-nuzul adalah sebab-sebab turunnya Al-Qur'an, maka ini menimbulkan pemahaman bahwa peristiwa atau pertanyaan yang terjadi pada masa Nabi itu lah yang menyebabkan diturunkannya Al-Qur'an, sehingga seandainya peristiwa atau pertanyaan itu tidak ada maka Al-Qur'an tidak jadi turun. ${ }^{13}$ Problem teologis lainnya adalah jika secara teologis Al-Qur'an dipahami sudah ada sejak zaman azali, dan dalam logika pengertian asbab al-nuzul di atas Al-Qur'an adalah sesuatu yang disebabkan (baca: akibat dari sebab), maka bagaimana bisa terjadi AlQur'an sebagai sesuatu yang disebabkan keberadaannya mendahului peristiwa/pertanyaan sebagai sesuatu yang menyebabkan turunnya Al-Qur'an. ${ }^{14}$

Menanggapi problem teologis di atas, sebagaimana dikutip dari Mu'amar Zayn Qadafy, Ibrahim al-Na'mah berpendapat bahwa penggunaan istilah asbabun nuzul adalah sekedar 'agar enak disebut saja' (min bab al-tasamuh wa al-tajawuz). Adapun istilah yang tepat adalah munasabat al-nuzul (relevansi peristiwa diturunkannya AlQur'an). ${ }^{15}$ Namun demikian, istilah asbabun nuzul lebih popular daripada munasabat al-nuzul, sehingga dengan ini dapat direkomendasikan bahwa penggunaan istilah tetap asbab al-nuzul tetapi dengan maksud (makna) munasabat al-nuzul.

Apakah Engkau mengumpulkan kami hanya untuk (mendengarkan) peringatan ini?' Kemudian peristiwa ini direspon oleh Allah dengan turun QS. Al-Lahab.

${ }^{12}$ Contoh pengaduan seorang perempuan bernama Khaulah binti Sa'labah kepada Rasulullah mengenai zihar yang dijatuhkan suaminya (Aus bin Samit) kepeda dirinya. Pengaduan ini ia lakukan karena merasa perlakuan suaminya cenderung tidak adil kepada dirinya. Ia telah menghabiskan masa mudanya bersama suaminya dan juga telah melahirkan banyak anak darinya, akan tetapi ketika sudah tua, ia di zihar oleh suaminya (zihar dalam tradisi Jahiliyah sama dengan thalaq). Aduan Khaulah binti Sa'labah ini kemudian direspon oleh Al-Qur'an dengan turunnya QS. Al-Mujadilah: 1-4.

${ }^{13}$ Dalam hal ini, Nashruddin Baidan juga menyatakan bahwa term 'sebab' di sana tidak sama dengan "sebab" sebagaimana yang dipahami dalam hukum kausalitas. Term 'sebab' dalam hukum kausalitas adalah kewajiban adanya untuk lahirnya suatu akibat, sehingga sebuah akibat tidak mungkin terjadi tanpa adanya sebab tertentu yang mendahuluinya. Akan tetapi yang dimaksud dengan 'sebab' dalam konteks ini, adalah sebab yang secara teoritis tidak mutlak adanya untuk turunnya sebuah ayat, walaupun secara empiris sebab (peristiwa) tersebut sudah terjadi. Keberadaan peristiwa/pertanyaan yang dinyatakan sebagai sebab-sebab turunya al-Qur'an, adalah salah satu manifestasi dari kebijaksanaan Allah dalam membimbing hamba-Nya. Dengan adanya asbabun nuzul, menjadi lebih tampak keabsahan Al-Qur'an sebagai petunjuk yang sesuai dengan kebutuhuan dan kesanggupan manusia. Nashruddin Baidan, Wawasan Baru Ilmu Tafsir (Yogyakarta: Pustaka Pelajar, 2005), 132.

${ }^{14}$ Belum lagi jika dihadapkan pada kasus surat al-Lahab. Keberadaan Al-Qur'an yang diyakini sudah ada di Lauh Mahfuz yang hal itu berarti keberadaan surat al-lahab juga sudah ada semenjak di Lauh Mahfuz, maka 'seakan-akan' Allah harus membuat di muka bumi seorang yang bernama Abu Lahab demi menjadi sebab diturunkannya surat al-Lahab. Kalau demikian halnya, maka dapat menimbulkan pemahaman bahwa Abu Lahab bukanlah sosok manusia kafir yang menentang dan memusuhi Nabi, tetapi ia adalah 'tumbal' yang berjasa menjadi penyebab diturunkannya surat al-Lahab.

${ }^{15}$ Mu'amar Zayn Qadafy, Sababun Nuzul Sebuah Kajian Epistemologis (Yogyakarta: IN AzNa Books, 2015), 17. 


\section{Sejarah Perkembangan Asbabun Nuzul}

Asbab al-nuzul menjadi sebuah ilmu ditandai dengan adanya para ulama yang secara spesifik menyusun karya-karya tentang asbab al-nuzul. Di antara para ulama tersebut adalah al-Wahhidi (w. $468 \mathrm{H}$ ) dengan karyanya yang berjudul Asbabun Nuzul al-Qur'an. ${ }^{16}$ Al-Wahhidi dalam karyanya ini, belum mendefinisikan asbab al-nuzul secara kongkrit. Ia menyebutkannya dengan menggunakan istilah qissatu al-ayat wa bayanu nuzuliha (cerita ayat dan penjelasan mengenai turunnya). Dengan ini, sekalipun al-Wahhidi belum sampai pada teoritisasi ilmu asbabun nuzul secara jelas, akan tetapi jelas bahwa ia sudah memiliki kesadaran tentang pentingnya penjelasanpenjelasan mengenai turunnya ayat-ayat Al-Qur'an.

Tokoh asbabun nuzul berikutnya adalah al-Ja'bari (w. $732 \mathrm{H}$ ) dengan karyanya yang merupakan ringkasan dari karya al-Wahhidi. Perkembangan teoritisasi asbabun nuzul yang dilakukan oleh al-Ja'bari dalam hal ini adalah pembagian turunnya AlQur'an ke dalam dua cara; pertama, ayat-ayat yang turun dengan sendirinya (ibtida'an), dan kedua, ayat-ayat yang turun setelah terjadinya suatu peristiwa ataupun adanya pertanyaan ('uqba hadisatin/su'alin). ${ }^{17}$

Selanjutnya, teoritisasi asbabun nuzul dikembangkan lagi oleh al-Zarkasyi dengan karyanya yang berjudul Al-Burhan Fi Ulum Al-Qur'an. ${ }^{18}$ Teori yang disumbangkan oleh al-Zarkasyi kaitannya dengan pengembangan ilmu asbabun nuzul adalah pengulangan turunnya ayat (tikrar al-nuzul). Teori ini muncul dilatarbelakangi oleh adanya problematika terkait satu ayat yang memiliki dua riwayat sabab al-nuzul. Melalui teori ini, maka disimpulkan bahwa jika satu ayat memiliki dua sabab al-nuzul yang berbeda namun sama-sama valid, ataupun memiliki satu riwayat akan tetapi isinya bertentangan dengan pemahaman umum mengenai ayat tersebut, maka ayat tersebut mengalami pengulangan turunnya. ${ }^{19}$

Dalam waktu hampir bersamaan dengan al-Zarkasyi, tokoh asbab al-nuzul berikutnya adalah Ibnu Hajar al-Asqalani (w. $852 \mathrm{H}$ ) dengan karyanya yang berjudul al- 'Ujab fi Bayan al-Asbab. ${ }^{20}$ Sumbangan keilmuan asbab al-nuzul dari Ibnu Hajar alAsqalani adalah menambahkan penjelasan-penjelasan yang belum (tidak) ada di kitabnya al-Wahhidi. Semangatnya adalah memilah dan memilih riwayat-riwayat yang bukan sebagai asbab al-nuzul dan riwayat-riwayat yang sebagai asbab al-nuzul. ${ }^{21}$

\footnotetext{
${ }^{16}$ Jika merujuk pada al-Zarkasyi, memang dikatakan bahwa tokoh pertama ilmu asbabun nuzul adalah Ali al-Madini (w. 234 H.) dengan karyanya Kitab al-Tanzil, namun demikian kitab tersebut tidak pernah ditemukan atau dijadikan rujukan oleh para ulama ilmu-ilmu Al-Qur'an. Dengan ini, al-Wahhidi tetap dianggap sebagai tokoh pertama ilmu asbabun nuzul. Qadafy, Sababun Nuzul Sebuah Kajian Epistemologis,3.

${ }^{17}$ Qadafy, Sababun Nuzul Sebuah Kajian Epistemologis, 23.

${ }^{18}$ Al-Zarkasyi, Al-Burhan fi Ulumil Qur'an (Kairo: Dar al-Hadis, 2006).

${ }^{19}$ Dikutip dari Mu'amar Zayn Qadafy, Sababun Nuzul, 25.

${ }^{20}$ Ibnu Hajar al-Asqalani, al- 'Ujab fi Bayan al-Asbab (Beirut: Dar Ibni Hazm, t.th.).

${ }^{21}$ Mu'amar Zayn Qadafy, Sababun Nuzul, 28.
} 
Perkembangan ilmu asbab al-nuzul berikutnya dipelopori oleh al-Suyuti (w. 911 H) dengan karyanya yang berjudul Lubab al-Nuqul Fi Asbab al-Nuzul. ${ }^{22}$ Dalam hal ini, ada beberapa sumbangan keilmuan yang sangat signifikan dari al-Suyuti. Pertama, alSuyuti berhasil mendefinisikan asbab al-nuzul dengan lebih jelas dan kongkrit. Asbab al-nuzul ia definisikan dengan "Ma nuzilat al-ayat ayyama wuqu'ihi" (sesuatu yang terjadi pada hari-hari diturunkannya ayat Al-Qur'an). Dalam definisi tersebut, alSuyuti menggunakan istilah 'ayyama' (hari-hari) maksudnya adalah peristiwa yang melatarbelakangi diturunkannya Al-Qur'an tersebut terjadi secara langsung ataupun peristiwa yang melatarbelakangi tersebut berjeda beberapa hari sebelum diturunkannya Al-Qur'an.

Kedua, al-Suyuti berhasil meyakinkan diterimanya riwayat asbab al-nuzul sebagai riwayat yang berstatus marfu' sekalipun ia hanya berhenti pada tabaqat sahabat (mauquf). Bahkan ia juga merekomendasikan diterimanya riwayat asbab alnuzul yang berstatus maqtu' (diriwayatkan oleh tabi'in) asalkan riwayat tersebut dikuatkan oleh riwayat lain dari para ulama tafsir yang diyakini mereka mendapatkannya dari para sahabat.

Ketiga, al-Suyuti juga berhasil merumuskan kategorisasi riwayat asbab al-nuzul ke dalam dua kategori, yaitu sarihah dan ghairu sarihah. Dikatakan sarihah jika riwayat asbab al-nuzul tersebut dinyatakan dengan: 'sababu nuzuli hadzihil ayat kadza...' atau riwayat tersebut diawali dengan huruf fa', seperti pernyataan 'hadasa kadza aw suila Rasulullah 'an kadza fa nazalat al-ayat...' dan dikatakan gairu sarihah jika riwayat asbab al-nuzul tersebut diawali dengan kata semisal "nazala kadza fi..." atau pernyataan 'ahsibu hadzihil ayat nazalat fi kadza...' Dengan adanya kategorisasi ini, al-Suyuti berhasil menyelesaikan problem yang selama ini dihadapi oleh ulama pendahulunya terkait dengan ketidakpastian apakah sebuah riwayat tersebut sebagai asbab al-nuzul ataukah sebagai tafsir dari ayat yang dimaksud. ${ }^{23}$

Khazanah ilmu asbab al-nuzul pada fase berikutnya dikembangkan oleh tokoh yang bernama al-Zarqani $(1367 \mathrm{H})$ dengan karyanya yang berjudul Manahil al-'Irfan Fi Ulumil Qur'an. ${ }^{24}$ Dalam karyanya ini, al-Zarqani mendefinisikan asbab al-nuzul secara lebih terperinci lagi. Menurutnya, asbab al-nuzul adalah "Suatu (peristiwa) yang terjadi yang kemudian karenanya suatu ayat (beberapa ayat) diturunkan untuk merespon peristiwa tersebut ataupun untuk menjelaskan hukumnya". Secara umum, definisi alZarqani ini memang tidak jauh berbeda dengan definisi tokoh sebelumnya (baca: alSuyuti), namun demikian dengan definisi al-Zarqani ini definisi asbab al-nuzul yang dikemukakan oleh al-Suyuti seakan menjadi semakin terpahami, karena adanya penjelasan yang lebih terperinci, yaitu suatu peristiwa yang dimaksud sebagai asbab alnuzul bukanlah sembarang peristiwa yang terjadi sesaat sebelum suatu ayat diturunkan, akan tetapi peristiwa yang terjadi dan memiliki keterkaitan langsung

\footnotetext{
${ }^{22}$ Al-Suyuti, Lubab al-Nuqul Fi Asbab al-Nuzul (Beirut: Mu'assasah al-Kutub al-Saqafiyyah, 2002).

${ }^{23}$ Mu'amar Zayn Qadafy, Sababun Nuzul, 32.

${ }^{24}$ Al-Zarqani, Manahil 'Irfan Fi Ulum al-Qur'an, Jilid I (Beirut: Dar al-Fikr, 1988).
} 
dengan isi dari ayat yang diturunkan, dengan dua indikasai, yaitu peristiwa tersebut direspon oleh ayat atau peristiwa tersebut dijelaskan hukumnya oleh ayat yang turun. ${ }^{25}$

Definisi asbab al-nuzul al-Zarqani yang komprehensif di atas dianggap sudah final dan mapan karena dalam perkembangan berikutnya para pakar sama mencukupkan diri untuk merujuk pada definisi tersebut atau sebagian dari mereka ada yang sekedar membahasakan ulang, seperti Manna' Khalil al-Qattan dalam karyanya yang berjudul Mabahis fi Ulumil Qur'an. ${ }^{26}$ Dalam karya tersebut ia mendefinisikan asbab al-nuzul dengan "suatu peristiwa atau pertanyaan yang karenanya Al-Qur'an diturunkan". 27

\section{Signifikansi Asbabun Nuzul}

Berdasarkan paparan di atas mengenai perkembangan ilmu asbab al-nuzul, jelas bahwa ilmu ini memiliki urgensi yang sangat tinggi dalam kajian tafsir al-Qur'an. AlQur'an yang notabene-nya adalah kalam Ilahi yang mewujud dalam bentuk teks diyakini penurunannya sangat berhubungan dengan dinamika sejarah dan setting social masyarakat Arab pada saat itu, bahkan pada kasus tertentu suatu ayat diturunkan sebagai respon langsung terhadap peristiwa-peristiwa khusus ataupun sebagai jawaban dari pertanyaan-pertanyaan khusus. Dengan ini, memahami Al-Qur'an tanpa melibatkan disiplin ilmu asbab al-nuzul bisa menyebabkan kesalahan pemahaman yang bersifat fatal. $^{28}$

Pentingnya kajian asbab al-nuzul dalam studi tafsir Al-Qur'an, para pakar dan pemerhati studi Qur'an merumuskannya ke dalam beberapa point berikut ini: ${ }^{29}$

a. Mengetahui hikmah disyari' atkannya sebuah hukum (Hikmatu Tasyri' al-Hukm)

b. Memastikan makna Al-Qur'an dan menghilangkan kerancuan (al-Wuquf 'ala alma'na wa izalat al-syakk)

c. Menghilangkan kerancuan dari pembatasan hukum (daf'u tawahhum al-hasr)

\section{Kaidah-kaidah Asbabun Nuzul}

Dalam pergulatan menentukan makna Al-Qur'an melalui kajian asbabun nuzul, dalam praktiknya paling tidak ada dua kaidah yang berkembang. Kedua kaidah tersebut adalah Al-ibratu Bi 'umumil lafaz la bikhushush al-sabab dan Al-Ibratu bikhushush alsabab la bi 'umumil lafaz.

\section{Kaidah Al-ibratu Bi 'Umumil Lafaz La Bikhushush al-Sabab}

Kaidah ini dapat diartikan dengan sebuah ketetapan hukum ('ibrah) itu didasarkan pada keumuman lafaz bukan pada kekhususan sebab. Dengan kaidah ini,

${ }^{25}$ Mu'amar Zayn Qadafy, Sababun Nuzul, 34-35.

${ }^{26}$ Manna' Khalil al-Qattan, Mabahis Fi Ulumil Qur'an (Beirut: Maktabah al-Ma'arif, 2000).

${ }^{27}$ Mu'amar Zayn Qadafy, Sababun Nuzul, 36.

${ }^{28}$ Sebagaimana pernyataan al-Wahhidi: 'La yumkinu ma'rifah tafsir al-ayat duna al-wuquf 'ala qishatiha wa bayan nuzuliha"(tidak mungkin mengetahui tafsir sebuah ayat tanpa memperhatikan cerita dan keterangan mengenai turunnya ayat tersebut. Dikutip Qadafy, Sababun Nuzul, 5.

${ }^{29}$ Qadafy, Sababun Nuzul,7-30. 
sebuah ayat dipahami berdasar redaksinya yang umum sekalipun dilatarbelakangi oleh sebab yang khusus, makna dari ayat tersebut tetap berlaku untuk semuanya. Contohnya QS. Al-Nur: 6:

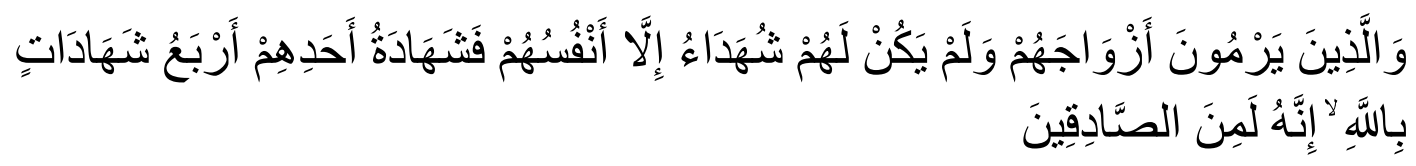

Artinya: "Dan orang-orang yang menuduh isterinya (berzina), padahal mereka tidak ada mempunyai saksi-saksi selain diri mereka sendiri, maka persaksian orang itu ialah empat kali bersumpah dengan nama Allah, sesungguhnya dia adalah termasuk orang-orang yang benar". (QS. Al-Nur [24]: 6). ${ }^{30}$

Ayat di atas turun berkaitan dengan kasus Hilal bin Umayah yang menuduh istrinya berzina dengan ibn Syuarik bin Samha'. Kemudian Nabi bersabda: 'Harus ada bukti, kalau tidak, maka punggungmu akan aku dera! Hilal berkata: 'Wahai Rasulullah, apabila salah seorang di antara kami melihat seorang laki-laki mendatangi istrinya, maka apakah dia harus mendatangkan bukti? Rasulullah menjawab; 'Harus ada bukti, jika tidak maka punggungmu akan aku dera! Hilal kemudian bersumpah: 'Demi Dzat yang mengutusmu dengan kebenaran, sesungguhnya aku adalah orang yang jujur dan Allah sungguh akan menyelamatkanku dari dera! Maka turunlah ayat di atas. ${ }^{31}$

Dengan kaidah al-ibratu Bi 'umumil lafaz la bikhushush as-sabab, maka ayat di atas sekalipun sebagai respon terhadap peristiwa khusus yaitu tuduhan zina yang dilontarkan Hilal bin Umayah kepada istrinya, akan tetapi keberlakuannya bersifat umum, yaitu berlaku untuk semua suami yang menuduh istrinya berzina supaya mendatangkan saksi atau kalau tidak ia harus bersumpah empat kali atas nama Allah.

\section{Kaidah Al-Ibratu Bikhushush al-Sabab La Bi 'Umumil Lafaz}

Kaidah ini adalah kebalikan dari kaidah di atas. Jika kaidah di atas mendasarkan hukum pada keumuman lafaznya, maka kaidah menyatakan bahwa suatu ketetapan hukum itu didasarkan pada sebabnya yang khusus bukan pada lafaznya yang umum, sehingga keberlakuan ayat tersebut tidak diperuntukkan untuk semuanya. ${ }^{32}$ Contohnya QS. Al-Baqarah: 115:

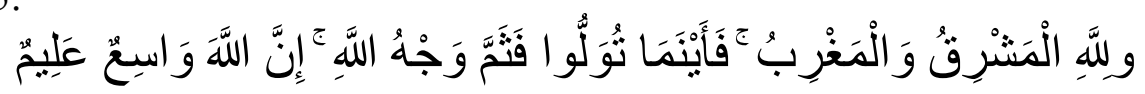

Artinya: "Dan kepunyaan Allah-lah timur dan barat, maka kemanapun kamu menghadap di situlah wajah Allah". (QS. Al-Baqarah [2]: 115). ${ }^{33}$

${ }^{30}$ Departemen Agama RI, Al-Qur'an dan Terjemahnya (Semarang: CV ALWAAH, 1993), 544.

${ }^{31}$ Manna' Khalil al-Qattan, Mabahis, 84.

${ }^{32}$ Oleh sebagian ulama, kaidah ini dijadikan sebagai counter terhadap kaidah sebelumnya. Mereka berargumen; 1) tujuan utama dari satu ayat yang turun dengan redaksinya yang umum adalah untuk menjelaskan satu hukum yang sebabnya khusus; 2) jika tetap yang dipegang adalah keumuman lafal, maka menjadi sia-sia kajian tentang riwayat asbabun nuzul, karena riwayat tersebut berdasar pada sebab yang khusus; 3) satu ayat yang beredaksi umum, terkadang adalah jawaban dari pertanyaan khusus, sedangkan jawaban dan pertanyaan akan memiliki kesesuaian dengan yang lainnya, jika adanya kesamaan kasus, situasi, dan kondisi. Mu'amar Zayn Qadafy, Sababun Nuzul, 41-43.

${ }^{33}$ Departemen Agama RI, Al-Qur'an, 31. 
Ayat di atas turun berkaitan dengan keadaan Nabi yang melaksanakan shalat di atas unta tunggangannya ketika dalam perjalanan dari Mekkah menuju Madinah. Sedangkan maklum adanya bahwa posisi Madinah adalah membelakangi Makkah. Berdasarkan kaidah Al-Ibratu bikhushush as-sabab la bi 'umumil lafaz maka ayat di at as dipahami bahwa kebolehan shalat menghadap arah mana saja adalah hanya berlaku untuk keadaan khusus, yaitu shalat di atas kendaraan atau keadaan lain yang bisa dikiaskan dengan keadaan khusus tersebut.

\section{Konstruksi Ilmu Asbabun Nuzul}

Dari gambaran umum tentang asbabun nuzul di atas, maka secara singkat konsep asbabun nuzul dapat dikonstruksikan sebagai berikut:

Asbabun nuzul adalah salah satu cabang Ulumul Qur'an yang mengkaji tentang sebab-sebab yang melatarbelakangi diturunkannya Al-Qur'an. Sebab-sebab tersebut adakalanya berupa peristiwa dan adakalanya berupa pertanyaan, kemudian Al-Qur'an turun merespon peristiwa tersebut ataupun menjawab pertanyaan tersebut. Dengan kajian asbabun nuzul ini, dapat dipahami bahwa Al-Qur'an tidak turun di ruang dan waktu yang hampa sejarah, melainkan ia berdialektika dengan realitas dan atau masyarakat yang diajaknya bicara. Al-Qur'an turun berinteraksi langsung dengan masyarakat Arab, baik dalam rangka memberi penjelasan ataupun memberi solusi atas problem yang dihadapi masyarakat Arab saat itu. Dengan dialektika dan interaksi seperti ini, keberadaan Al-Qur'an benar-benar membumi dan menyejarah di tengahtengah kehidupan manusia (baca: masyarakat Arab saat itu).

Oleh karena asbabun nuzul itu berupa peristiwa atau pertanyaan, maka satusatunya data (informasi) yang valid tentang hal itu adalah melalui tuturan (periwayatan) para sahabat yang terlibat atau menyaksikan turunnya Al-Qur'an. Dalam tuturannya ini, sahabat biasanya menggunakan ungkapan: "Sebab turunnya ayat ini adalah..." atau uangkapan: "Rasulullah ditanya, kemudian turunlah ayat..." Informasi ini sekalipun dari sahabat (mauquf), ${ }^{34}$ akan tetapi ia dihukumi sama seperti (seakan) dari Nabi (marfu'). ${ }^{35}$ Hal ini karena Nabi Muhammad sebagai actor utama (figur sentral yang Al-Qur'an diturunkan kepadanya) tentu tidak mungkin menceritakan sendiri kepada dirinya mengenai sejarah turunnya Al-Qur'an.

Asbabun nuzul sebagai sebab-sebab turunnya Al-Qur'an, tentu kajian terhadapnya sangat penting, khususnya sebagai pisau analisis untuk memahami makna dan atau menentukan hukum yang dimaksudkan oleh Al-Qur'an. Kajian terhadap asbabun nuzul mengantarkan pada pengetahuan apakah makna sebuah ayat itu berlaku khusus (lokal/temporal) ataukah umum (universal). Tanpa pengetahuan ini, seseorang

\footnotetext{
${ }^{34}$ Hadis mauquf adalah perkataan atau perbuatan yang disandarkan pada sahabat Nabi, baik sanadnya bersambung atau terputus. Misalnya, Ibnu Umar berkata: , Ibnu Mas'ud berkata: ... Muhammad Alwi al-Maliki al-Hasani, Al-Minhal al-Lathif Fi Ushul Al-Hadis Al-Syarif (Surabaya: Hai'ah Ash-Shafwah Al-Malikiyah, t.th.), 75.

${ }^{35}$ Hadis Marfu' adalah segala perkataan, perbuatan, dan ketetapan yang disandarkan kepada NAbi SAW. Misalnya, Rasulullah bersabda Al-Hasani, Al-Minhal al-Lathif, 69.
} 
bisa saja salah memahami sebuah ayat Al-Qur'an; mestinya ayat tersebut berlaku khusus tapi dipahami berlaku umum atau sebaliknya. Dengan kata lain, dengan mengkaji asbabun nuzul, seseorang dalam memahami sebuah ayat Al-Qur'an bisa menentukan penggunaan kaidah al- 'ibratu bi 'umum al-lafadz la bi khushush al-sabab' ataukah penggunaan kaidah al-'ibratu bi khushush al-sabab la bi 'umum al-lafadz. Contoh QS. Al-Baqarah: 115 yang terjemahnya: "Dan kepunyaan Allah-lah timur dan barat, maka kemana pun kamu menghadap di situlah wajah Allah". Ayat ini berkaitan dengan pelaksanaan ibadah shalat. Jika tidak dikaji asbabun nuzulnya, maka bisa saja seseorang memahaminya sesuai dengan keumuman lafadznya, yaitu shalat boleh menghadap ke mana saja karena ke mana pun menghadap di sana ada Allah. Akan tetapi setelah dikaji asbabun nuzulnya, ayat ini berkaitan dengan shalat dalam perjalanan atau shalat dalam keadaan buta arah kiblat, sehingga dalam kondisi khusus seperti ini shalat boleh dilakukan menghadap ke mana saja. Dengan ini, kaidah yang tepat untuk digunakan memahami QS. Al-Baqarah: 115 di atas adalah kaidah al-'ibratu bi khushush al-sabab la bi 'umum al-lafadz.

\section{Dekonstruksi Ilmu Asbabun Nuzul}

Paparan asbabun nuzul sebagaimana konstruksi di atas jika ditinjau dari pergeseran paradigma Thomas Kuhn dapat dikatakan sebagai normal sains (normal science). ${ }^{36}$ Dikatakan normal sains karena konsep asbabun nuzul tersebut dianggap sudah mapan dan final. Namun demikian, jika ditelisik lebih jauh dan dihadapkan pada isu-isu kekinian, maka tampak bahwa konstruksi ilmu asbabun nuzul sebagaimana yang dikonsepsikan ulama di atas mengalami 'ketidakcukupan' (untuk enggan mengatakan: ketidakmampuan) dalam menghadapi kondisi dan realitas kekinian yang semakin kompleks.

Memang, konsepsi asbabun nuzul di atas sudah cukup menyelesaikan problem pemahaman ayat yang memiliki sabab-sebab turunnya. Akan tetapi permasalahannya adalah, tidak semua ayat Al-Qur'an memiliki asbabun nuzul. ${ }^{37}$ Bahkan ayat-ayat yang tidak memiliki asbabun nuzul jumlahnya lebih banyak daripada ayat-ayat yang memiliki asbabun nuzul. Lalu, bagaimanakah menyelesaikan problem pemahaman pada ayat-ayat yang tidak ber-asbabun nuzul tersebut?

Kebutuhan kekinian, problem pemahaman ayat tidak hanya sekedar menentukan sebab khusus ataukah lafadznya yang umum, akan tetapi problem yang ada adalah menentukan maqashid dari sebuah ayat, atau bahkan maqashid dari Al-Qur'an itu sendiri. Sehingga dengan ini, bisa jadi sebuah ayat, sekalipun dari segi penunjukkannya jelas (dalalah sharihah), akan tetapi sekiranya ayat tersebut dipraktekkan sesuai dengan penunjukkannya malah bertentangan dengan maqashid Al-Qur'an, maka ayat tersebut dianggap sebagai furu' Al-Qur'an (cabang) yang penerapannya harus diacukan kepada ushul (maqashid) Al-Qur'an. Dengan ini, (mengacu pada paradigma Thomas Kuhn)

\footnotetext{
${ }^{36}$ Thomas Kuhn, The Structure of Scientific Revolutions, Jilid 2 No. 2 (London: The University of Chicago Press, 1962), 10.

${ }^{37}$ Al-Suyuti, Al-Itqan Fi Ulum al-Qur'an, Jilid I, 29. Al-Zarqani, Manahil..., Jilid I, 106.
} 
berarti asbabun nuzul sebagai normal sains telah mengalami anomaly atau bahkan krisis. Misalnya dalam memahami QS. Al-Maidah: 38:

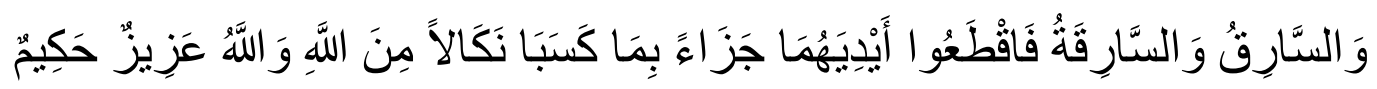

Artinya: "Laki-laki yang mencuri dan perempuan yang mencuri, potonglah tangan keduanya (sebagai) pembalasan bagi apa yang mereka kerjakan dan sebagai siksaan dari Allah. Dan Allah Maha Perkasa lagi Maha Bijaksana.” (QS. AlMaidah [5]: 38). ${ }^{38}$

Ayat di atas, jika dikaji asbabun nuzulnya adalah berkenaan dengan Thu'mah bin Ubairiq yang mencuri baju perang kepunyaan Qatadah bin Al-Nu'man (yang tidak lain adalah tetangga Thu'mah sendiri). Baju perang tersebut kemudian disembunyikan di rumah seorang Yahudi yang bernama Zaid bin Al-Samin. Akan tetapi, tanpa disadari kantong yang berisi tepung yang dibawa Thu'mah sewaktu mencuri ternyata bocor sehingga tercecerlah tepung tersebut mulai dari rumah Qatadah bin al-Nu'man sampai rumah Zaid bin al-Samid. Dari sinilah kemudian menjadi ketahuan (ketangkap) siapa pencurinya, karena Qatadah kemudian menyusuri ceceran tepung tersebut hingga ia sampai ke rumah Zaid bin al-Samid dan mendapati baju perangnya ada di rumah tersebut. Lalu Qatadah mengambil baju perangnya dan Zaid berkata: "Saya diberi baju perang ini oleh Thu'mah bin Ubairiq". Kemudian orang-orang pada bersaksi membenarkan perkataan Zaid hingga turunlah ayat di atas.

Dari kajian terhadap asbabun nuzulnya di atas, maka QS. Al-Baqarah: 115 ini memiliki sebab khusus menyangkut turunnya, yaitu pencurian yang dilakukan oleh Thu'mah bin Ubairiq. Namun demikian, berdasar petunjuknya, QS. Al-Baqarah: 115 ini menuntut untuk dipahami berdasar redaksinya yang umum. Dengan demikian berlaku kaidah al-'ibrah bi 'umum al-lafadz la bikhusus al-sabab, sehingga ayat di atas dpahami sekalipun hukuman potong tangan tersebut dikenakan kepada Thu'mah bin Ubairiq, bukan berarti bahwa pencuri-pencuri lain tidak dikenakan hukum potong tangan. Thu'mah bin Ubairiq di ayat itu hanyalah perantara (sampel) untuk diterapkannya hukum potong tangan bagi pencuri, sehingga keberlakuan hukum potong tangan tersebut bersifat umum (berlaku bagi siapa saja yang melakukan kejahatan pencurian sebagaimana pencurian yang dilakukan oleh Thu'mah bin Ubairiq).

Pemahaman seperti ini, pada awalnya memang dianggap sudah tuntas dan tidak menyisakan masalah (normal sains), akan tetapi seiring dengan berkembangnya zaman; umat Islam tidak semuanya hidup dalam negara yang menerapkan hukum Islam; model dan bentuk pencurian juga tidak semuanya menggunakan tangan tapi bisa dengan jabatan dan kekuasaan; system penegakkan hukum yang ada tekadang juga tidak seadil dulu, maka penerapan ayat di atas secara apa adanya tanpa mempertimbangkan

\footnotetext{
${ }^{38}$ Departemen Agama RI, Al-Qur'an, 165.
} 
kompleksitas kondisi dan realitas kekinian, bisa jadi hal tersebut malah menimbulkan Al-Qur'an kontraproduktif dengan maqashid-nya (anomali dan krisis).

\section{Rekonstruksi Ilmu Asbabun Nuzul}

Dari paparan di atas, tampak bahwa ilmu asbabun nuzul telah mengalami pergeseran paradigma (shifting paradigm); dari semula menjadi normal sains seiring dengan kompleksitas kondisi dan realitas yang ada berubah menjadi anomali dan krisis. Pada fase ini, dapat dikatakan telah terjadi kesenjangan (gab) antara teori yang ada dengan permasalahan yang dihadapi. Untuk itu diperlukan sebuah paradigma baru (new paradigm) agar masalah baru yang dihadapi senantiasa dapat diselesaikan dengan teori baru yang lebih memadai. Di sinilah rekonstruksi ilmu asbabun nuzul itu perlu dilakukan dan mendapatkan momentum signifikansinya.

Dalam uraian mengenai dekonstruksi ilmu asbabun nuzul di atas, paling tidak ada dua kesenjangan yang dialami oleh ilmu asbabun nuzul lama (klasik); aspek kajian dan aspek temuan. Aspek kajian; ilmu asbabun nuzul lama (klasik) kajiannya hanya pada ayat-ayat yang ber-asbabun nuzul, sementara tidak semua ayat Al-Qur'an memiliki asbabun nuzul. Aspek temuan; ilmu asbabun nuzul lama (klasik) temuannya hanya makna (local-temporal) khusus atau makna umum (universal), belum sampai pada temuan makna maqashid.

Jika permasalahan mengenai dua gap di atas dikaji secara mendalam lagi, maka dapat ditemukan bahwa pangkal permasalahannya adalah terletak pada keterbatasan cakupan ilmu asbabun nuzul klasik terhadap data-data mengenai sejarah dan peristiwa yang melatarbelakangi turunnya Al-Qur'an. Data yang bisa disajikan oleh ilmu asbabun nuzul klasik (berupa riwayat-riwayat) bersifat khusus dan terbatas, sehingga tidak cukup mampu untuk menggambarkan konteks sejarah yang lebih luas diturunkannya Al-Qur'an.

Di sinilah, dalam upaya rekonstruksi ilmu asbabun nuzul maka sangat perlu adanya kajian tentang konteks sejarah yang lebih luas. Konteks sejarah yang lebih luas ini, bisa disebut dengan istilah asbabun nuzul makro. ${ }^{39}$ Secara sederhana, asbabun nuzul makro dapat didefinisikan dengan situasi dan kondisi secara umum dalam konteks apa dan kapan serta di mana Al-Qur'an diturunkan, ${ }^{40}$ atau dengan kata lain mengkaji asbabun nuzul makro berarti mengkaji situasi dan kondisi sosio-historis jazirah Arab dalam kisaran waktu abad $6 \mathrm{M}$, sebagai tempat dan waktu diturunkannya Al-Qur'an.

\footnotetext{
${ }^{39}$ Embrio asbabun nuzul makro ini bisa dirujuk pada al-Syatibi (W. 1388), ia menyatakan bahwa maksud mengetahui asbabun nuzul adalah mengetahui situasi dan kondisi orang-orang yang mengajak bicara, orang-orang yang diajak bicara, dan pembicaranya sendiri. Dikutip dari Syarafuddin H.Z., "Ilmu Asbabun Nuzul dalam Studi Ilmu Al-Qur'an”, dalam Jurnal Shuhuf 28, no.1 (2016): 84-94. Pendapat alSyatibi ini kemudian dalam konteks kekinian dipopulerkan oleh Fazlur Rahman, ia menyatakan asbabun nuzul meliputi situasi dan kondisi historis yang riil terjadi (social, budaya, politik, ekonomi, teknologi, psikologi Nabi, dan lain-lain). Fazlur Rahman, Islam, Terjemah Ahsin Mohammad (Bandung: Pustaka, 1984), 386.

${ }^{40}$ Said Agil Husin al-Munawwar dan Abdul Mustaqim, Asbabul Wurud Studi Krisis Hadis Nabi Pendekatan Sosio- Historis-Kontekstual (Yogyakarta: Pustaka pelajar, 2001), 21.
} 
Selanjutnya, oleh karena asbabun nuzul makro berupa situasi dan kondisi sosiohistoris jazirah Arab yang melingkupi turunnya Al-Qur'an, maka satu-satunya cara untuk mengetahui asbabun nuzul makro tersebut adalah dengan rekonstruksi sejarah. Rekonstruksi sejarah ini perlu, lebih-lebih dalam rangka mengembalikan unsur waktu (moment) yang hilang akibat kodifikasi Al-Qur'an ke dalam mushaf (korpus tertutup). Selain hal di atas, dikembangkannya paradigma baru mengenai asbabun nuzul makro dalam studi tafsir Al-Qur'an adalah adanya asumsi dasar bahwa pada saat Al-Qur'an turun pasti tidak lepas dari situasi dan kondisi yang melingkupi audiens-nya pada waktu itu, atau dengan kata lain Al-Qur'an turun pastilah mempunyai korelasi dan relevansi dengan umatnya. ${ }^{41}$ Dengan ini, maka penafsiran Al-Qur'an secara lebih akomodatif dan apresiatif terhadap perkembangan zaman dengan tidak mengabaikan unsur ratio legis-nya ${ }^{42}$ adalah sebuah keniscayaan yang tidak bisa ditawar lagi. ${ }^{43}$ Lebih jauh, pengetahuan tentang asbabun nuzul makro ini secara otomatis juga mengantarkan ke arah pengetahuan tentang maqashid Al-Qur'an. ${ }^{44}$

Konsekuensi dari pengetahuan tentang maqashid Al-Qur'an di atas adalah dirumuskannya kaidah baru yang berbunyi: Al-'ibratu bi al-maqashid, yaitu suatu keketapan (hukum) dari sebuah ayat itu didasarkan pada maqashid-nya. Misalnya dalam memahami QS. Al-Maidah: 38:

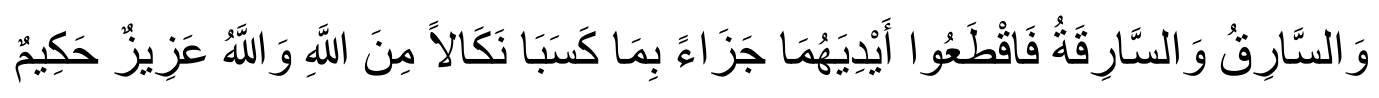

Artinya: "Laki-laki yang mencuri dan perempuan yang mencuri, potonglah tangan keduanya (sebagai) pembalasan bagi apa yang mereka kerjakan dan sebagai siksaan dari Allah. Dan Allah Maha Perkasa lagi Maha Bijaksana.” (QS. AlMaidah [5]: 38). ${ }^{45}$

Ayat di atas, jika dipahami dengan menggunakan kaidah Al-'ibratu bi almaqashid, kurang lebih secara sederhana dapat dikiaskan dengan penjelasan berikut ini. Misalnya, seorang Bapak memerintah anaknya, dengan berkata: Nak, nanti akan ada tamu ke rumah, tolong belikan jajanan pisang goreng di warung! Kemudian si anak segera bergegas ke warung, dan ternyata pisang goreng di warung tersebut sudah habis. 12.

${ }^{41}$ Asghar ali Engineer, The Qur'an, Women and Modern Society (New Delhi: Sterling Pub., 1999),

${ }^{42}$ Fazlur Rahman, Tema Pokok al-Qur'an, terj. Anas Mahyudin (Jakarta: Pustaka Pelajar, 1980), 70.

${ }^{43}$ Inilah yang dalam bahasa Hodson diistilahkan dengan pemahaman ber-"kesadaran historis", yang dengannya Islam akan mampu lebih baik dalam menjawab tantangan zaman di masa depan. Marshal G.S. Hodson, The Venture of Islam, Jilid 3 (Chicago: The University of Chicago Press, 1974), 437.

44 Satu hal yang harus disadari, kaitannya dengan penafsiran Al-Qur'an dengan pengetahuan tentang latar belakang sosio-historis munculnya sebuah ayat (asbabun nuzul makro) ini adalah adanya kendala besar untuk memperoleh data historis (rekonstruksi sejarah) tersebut secara objektif, apalagi dari suatu discourse yang sudah terlembagakan dalam bentuk teks, sehingga harus diakui bahwa dalam suatu interpretasi seperti ini tidak bisa terhindar dari adanya unsur tebakan (spekulasi), apropriasi, dan rekonstruksi imajinatif mengenai gagasan yang hendak dipahami dan diungkapkan sebuah teks. Sekalipun demikian, sebagai sebuah ijtihad tentunya sah-sah saja, karena kalau benar, kebenarannya pun bersifat nisbi (relatif), dan kalau salah, tetap mendapatkan pahala.

${ }^{45}$ Departemen Agama RI, Al-Qur'an, 165. 
Dalam kondisi seperti ini, si anak kemudian bingung, saya sebaiknya beli jajanan lainnya atau tidak jadi beli? Sampai akhirnya si anak memutuskan untuk membeli jajanan lain sebagai ganti pisang goreng. Si anak beralasan, bukan kah di rumah ada tamu, maka sepertinya maksud Bapak yang penting bukan lah harus pisang goreng, tetapi yang penting adalah harus ada jajanan yang disuguhkan. Dari sini, si anak melihat bahewa sekalipun secara redaksional kata pisang goreng sudah jelas disebut, tetapi maksud (maqashid) dari perkataan Bapaknya bukan lah di 'pisang goreng', tetapi maqashid-nya adalah harus adanya jajanan, disebutkannya pisang goreng hanyalah sebagai sampel, sehingga ia bisa diganti dengan jajanan lainnya, karena yang penting (maqashid-nya) adalah adanya jajanan suguhan untuk tamu. Dengan demikian, memaksakan diri untuk tetap membeli psang padahal pisang gorengnya sudah habis adalah keputusan yang dianggap kontraproduktif dengan maqashid dari pernyataan si Bapak.

Demikian pula kira-kira pemahaman ayat di atas, disebutkannya hukuman potong tangan secara jelas, bisa jadi bukan itu maqashid dari ayat tersebut. Maqshid dari ayat tersebut bisa jadi adalah yang penting adanya hukuman yang menjerakan bagi si pencuri. Hukuman potong tangan hanyalah sampel (pilihan) saat itu, oleh karenanya ia bisa diganti dengan hukuman lainnya, asal yang penting sama-sama memiliki efek jera. Memaksakan diri untuk tetap memilih hukuman potong tangan, sementara situasi, kondisi, dan praktek pencurian sudah berubah, bisa jadi malah kontraproduktif dengan maqashid ayat di atas.

\section{Penutup}

Berdasarkan paparan di atas, dapat diambil simpulan bahwa ilmu asbabun nuzul adalah ilmu yang senantiasa mengalami pengkayaan dan pengembangan. Pemgkayaan dan pengembangan ilmu ini, paling tidak bisa dilihat pada dua hal:

Pertama, ilmu asbabun nuzul, semula hanya sebatas ilmu yang mengkaji konteks sejarah khusus (mikro) turunnya sebuah ayat berbasis tuturan para sahabat, kemudian karena adanya anomaly dan krisis terkait dengan problematika memahami Al-Qur'ania berkembang menjadi sebuah ilmu yang mengkaji tentang konteks sejarah luas (makro) yang melingkupi turunnya Al-Qur'an berbasis rekonstruksi situasi dan kondisi sosio-historis jazirah Arab dalam kisaran waktu abad $6 \mathrm{M}$;

Kedua, ilmu asbabun nuzul, semula hanya focus pada problematika apakah sebuah ketetapan satu ayat itu berdasar redaksinya yang umum (al-'ibratu bi umum allafdzi) atau kah sebabnya yang khusus (al-ibratu bi khushush al-sabab), kemudian berkembang menjadi pergulatan mencari dan menemukan maqashid Al-Qur'an (alibratu bi al-maqashidi). 


\section{DAFTAR PUSTAKA}

Alifudin, Muhammad, “Asbabun Nuzul dan Urgensinya dalam Memahami Al-Qur'an”, dalam Shautut Tarbiyah, Ed. 26,Th. XVIII, Mei 2012.

Asqalani, Ibnu Hajar al-, al- 'Ujab fi Bayan al-Asbab, Beirut: Dar Ibni Hazm, t.th..

Baidan, Nashruddin, Wawasan Baru Ilmu Tafsir, Yogyakarta: Pustaka Pelajar, 2005.

Chirzin, Muhammad, Al-Qur'an dan Ulumul Qur'an, Yogyakarta: Dana Bhakti Prima Yasa, 1998.

Departemen Agama RI, Al-Qur'an dan Terjemahnya, Semarang: CV ALWAAH, 1993.

Engineer, Asghar Ali, The Qur'an, Women and Modern Society, New Delhi: Sterling Pub., 1999.

Hasani, Muhammad Alwi al-Maliki al-, Al-Minhal al-Lathif Fi Ushul Al-Hadis AlSyarif, Surabaya: Hai'ah Ash-Shafwah Al-Malikiyah, t.th.

Hodson, Marshal G.S., The Venture of Islam, Jilid 3, Chicago: The University of Chicago Press, 1974.

Madjid, Nurcholis, "Konsep Asbabun Nuzul: Relevansinya Bagi Pandangan Historis Segi-segi Tertentu Pandangan Keagamaan", dalam Budhy Munawar Rahman (ed.), Kontekstualisasi Doktrin Islam dalam Sejarah, Jakarta: yayasan Paramadina, 1994.

Munawwar, Said Agil Husin al- dan Abdul Mustaqim, Asbabul Wurud Studi Krisis Hadis Nabi Pendekatan Sosio- Historis-Kontekstual, Yogyakarta: Pustaka pelajar, 2001.

Qadafy, Mu'amar Zayn, Sababun Nuzul Sebuah Kajian Epistemologis, Yogyakarta: IN AzNa Books, 2015.

Qattan, Manna' Khalil al-, Mabahis Fi Ulumil Qur'an, Beirut: Maktabah al-Ma'arif, 2000.

Rahman, Fazlur, Islam, Terj. Ahsin Mohammad, Bandung: Pustaka, 1984.

Rahman, Fazlur, Tema Pokok al-Qur'an, terj. Anas Mahyudin, Jakarta: Pustaka Pelajar, 1980.

Shalih, Shubhi, Membahas Ilmu-ilmu Al-Qur'an, Terj. Nur Rakhim dkk., Jakarta: Pustaka Firdaus, 1993.

Shiddieqy, M. Hasbi Ash, Sejarah dan Pengantar Ilmu Al-Qur'an/Tafsir, Jakarta: Bulan Bintang, 1990.

Sisfita, Nunung, “Asbabun Nuzul Perspektif Mikro dan Makro', dalam Tasamuh 13, no. 1 (2015).

Suaedi, Pan, "Asbabun Nuzul Pengertian, Macam-macam, Redaksi, dan Urgensi", dalam Almufida 1, no. 1 (2018).

Suma, Muhammad Amin, Ulumul Qur'an, Cet. I, Jakarta: PT Raja Grafindo, 2013.

Suyuti, Al-, Lubab al-Nuqul Fi Asbab al-Nuzul, Beirut: Mu'assasah al-Kutub alSaqafiyyah, 2002.

Thomas Kuhn, The Structure of Scientific Revolutions, Jilid 2 No. 2, London: The University of Chicago Press, 1962.

Wahidi, Ridhaul, “Asbabun Nuzul sebagai Cabang Ulumul Qur'an”, dalam Jurnal Syahadah 3, no. 1 (2016).

Wahyudin, “Asbabun Nuzul sebagai Langkah Awal Menafsirkan Al-Qur'an”, dalam JSH Jurnal Sosial Humaniora 3, no. 1 (2010).

Zarkasyi, Al-, Al-Burhan fi Ulumil Qur'an, Kairo: Dar al-Hadis, 2006.

Zarqani, Al-, Manahil 'Irfan Fi Ulum al-Qur'an, Jilid I, Beirut: Dar al-Fikr, 1988. 